(1981)

11) Patterson, G.K.: PCH Physico. Chem. Hydrodyn., 7, 33-41 (1986)

12) Reid, R.C., J.M. Prausnitz and B.E. Poling: "The Properties of Gases and Liquids", p.598, McGraw Hill, New York (1988)

13) Takahashi, K.: "Ekitai Kongo Gijutsu" (Japanese translation of Harnby, N., M.F. Eewards and A. W. Ninow (Eds.)" Mixing in Process Industries"), p.48, Nikkan Kogyo Shinbun-sha (1989)

14) Tatterson, G.B.: "Fluid Mixing and Gas Dispersion in Agitated Tanks”, p.226-236, McGrawHill, New York (1991)

15) Wolfbeis, O.S., E. Fürlinger, H. Kroneis and H. Marsonar: Z. Anal. Chem., 314, 119-124 (1983)

16) Wu, H. and G.K. Patterson: Chem. Eng. Sci., 44, 2207-2221 (1989)

\title{
Development of a Local Mixing Measurement System Using Fluorescent $\mathrm{pH}$ Indicator
}

\author{
Yushi Hirofuji*, Taro Inoue ${ }^{* *}$ and Yoichi Nagase
}

Dept. Chem. Eng., Hiroshima Univ., Higashi-Hiroshima 724

Key Words : Micromixing Measurement, Local Mixing, Fluorescence, pH Indicator, Xenon

A simple system for measurement of resultant micromixing in a solution, in the sense of space average, has been developed. $\mathrm{NaOH}$ solution is injected into a solution including fluorescence $\mathrm{pH}$ indicator-8-hydroxy 1, 3,6-pyrene trisulfonic acid sodium salt (HOPSA) - of which the absorbance and fluorescence spectra bands are completely different from each other. A xenon light source is focused into a light-guide fiber which is introduced to a measurement point. Fluorescence light is detected by a photomultiplier with a pin-hole section. The system was applied to local mixing measurement in the impeller stream from a disc turbine. The response curve showed violent fluctuation with reasonable time delay.

* Fukuoka Industrial Technology Center

** Tokuyama Soda Co., Ltd.

\section{タンパク質を担持したパーフルオロカーボン液滴の調製と タンパク質分離への適用 ${ }^{\dagger}$}

\author{
上平正道・荻野倫明 - 竹内 寛

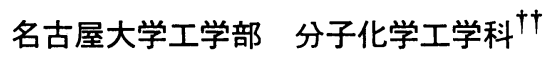

\section{緒言}

タンパク質は, 塩や有機溶媒による沈殿法や各種クロ マトグラフィーによって精製されている.クロマトグラ

\footnotetext{
† 1993年 7 月 12 日受理 ; 化学工学会第 25 回秋季大会 (東京, 1992年 9 月）にて発表

†† $7464-01$ 名古屋市千種区不老町
}

フィー法は分離能が高いためしばしば用いられる手法で あるが，スケールアップが容易ではないため，工業規模 での分離において有用な分離法は限られているのが現状 である. 一方, 液液抽出法は化学工学の基本的な単位操 作で，スケールアップが比較的容易で連続操作も可能で あるという利点を持っている。したがって，液液抽出法 
がタンパク質分離にも適用できれば，有効な工業的分離 法となりうる。しかしながらタンパク質は, 通常の有機 溶媒には溶解しないため, タンパク質の分離に適用可能 な液液抽出法は, 水性二相分配抽出法 ${ }^{11}$ や逆相ミセル抽 出法 ${ }^{3)}$ に限られている. てれらの方法は, 分離の特異性 などに問題があるため，工業規模での分離に適用可能な 新しいタイプの分離法の開発が望まれている.

パーフルオロカーボン $(\mathrm{PFC})$ は，炭化水素の水素が高 度にフッ素化した化合物であるが，化学的に安定で生体 に対して不活性である。また，酸素溶解性の高さを利用 して人工血液に用いられており, 微生物や動物細胞培養 に拈りる酸素キャリヤーとしてあ適用が試みられている 近年, PFCにタンパク質を導入し，PFCを微小液滴にし て分離用の担体として用いる分離方法が提案されてい $ろ^{2,51}$. PFCを分離用の担体として用いる際の利点として は, 非特異吸着が比較的少ないてと, 疎水性が高く比重 が大きいため水系との分離が容易であること，液体の担 体であるため固体担体と比べ実際上擋拌などによる剪断 応力に強いことなどがあげられる．

本研究では, 簡単・迅速活性を保持したタンパク質 を担持したPFC液滴の調製方法を開発し, 各種タンパク 質の液滴への固定化を検討した。さらに，タンパク質の 分離のために，PFC液滴の繰返し使用についても検討を 行った.

\section{1. 実験材料および方法}

\section{1 実験材料}

$\mathrm{PFC}$ として FC-43 (住友 $3 \mathrm{M}$ (株) 製)を用いた。パー フルオロベンゾイルクロリド (PFBC) は, 東京化成工業 （株）製を用いた．牛血清アルブミン，パーオキシダーゼ， $\beta$-グルコシダーゼ, コンカナバリン A およびヒト IgG は, Sigma Chemical Co.から, プロティンAは, Genzyme Co.から購入した. デキストラン(Dextran T 500) は, Pharmacia Fine Chemical Co. 製を使用した.

\section{$1.2 \mathrm{PFC}$ 液滴の作製方法}

直接法 $\mathrm{PFC} 1 \mathrm{~cm}^{3}$ 亿適当量 (通常 $0.001 \mathrm{~cm}^{3}$ ) の PFBCを溶解させ， $0.14 \mathrm{M} \mathrm{NaCl}$ を含む $50 \mathrm{mM}$ リン酸カ リウム緩衝液 $\left(\mathrm{pH} 7.4\right.$; PBS) 亿通常 $1 \mathrm{~g} / \mathrm{dm}^{3}$ の濃度の夕 ンパク質溶液 $1 \mathrm{~cm}^{3}$ 加えてVortex mixerで擋拌し, $\mathrm{pH}$ を $1 \mathrm{M} \mathrm{Na}_{2} \mathrm{CO}_{3}$ 溶液で調整しながら 2 時間反応させアシ ル化した，PFBCは，PFCに溶解する部分とタンパク質 の水酸基やアミノ基と共有結合的に結合する部分をむっ て抢り,タンパク質が適当量のPFBC で修飾されると $\mathrm{PFC}$ と水相の界面に配置し PFC が液滴になると考えら れる. 生成したPFC液滴相は, PBSで洗浄後使用した。

デキストラン媒介法 $\quad \mathrm{PFC} 1 \mathrm{~cm}^{3}$ に $\mathrm{PFBC} 0.01 \mathrm{~cm}^{3}$ 溶解し，1\%デキストラン水溶液を加えて $\mathrm{pH}$ を調整しな
Table 1 Introduction of proteins to PFC droplet-phase

\begin{tabular}{|c|c|c|}
\hline \multirow{2}{*}{ Protein } & \multicolumn{2}{|c|}{$\begin{array}{l}\text { Amount of protein introduced to } \\
\text { PFC-phase }\left[\mathrm{g} / \mathrm{dm}^{3}-\mathrm{PFC}\right]\end{array}$} \\
\hline & Direct method & $\begin{array}{c}\text { Dextran mediated } \\
\text { method }\end{array}$ \\
\hline Bovine serum albumin & 1.0 & 1.0 \\
\hline Peroxidase & $1.0(0.07)^{*}$ & $0.75(0.07)^{*}$ \\
\hline$\beta$-Glucosidase & $0.78(0.61)^{*}$ & $0.75(0.37)^{*}$ \\
\hline Protein A & $1.0(0.25)^{* *}$ & $0.40(0.33)^{* *}$ \\
\hline Concanavalin A & 1.0 & - \\
\hline
\end{tabular}

がらVortex mixer で擋拌するととによりデキストラン を取り込んだPFC液滴を調製した。調製したPFC 液滴 をPBSで洗浄後, $\mathrm{NaIO}_{4} 20 \mathrm{mg}$ を加えて 2 時間酸化した. PFC 液滴は洗浄後, PBSに溶解した $1 \mathrm{~g} / \mathrm{dm}^{3}$ のタンパク 質溶液 $1 \mathrm{~cm}^{3}$ と混合し，擋拌しながら一晚反応させた。 調製したPFC液滴相は，洗浄後使用した。

\section{3 分析方法}

タンパク質濃度は, Lowry 法 $^{6)}$ により測定した。 パー

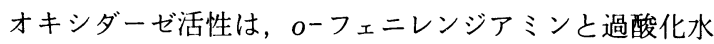
素を基質として， $\beta$-グルコシダーゼ活性は， $p$-ニトロ フェニルグルコピラノシドを基質として比色法により決 定した。

\section{2. 結果および考察}

各種タンパク質をPFCへ担持した結果を Table 1 亿示 す. 直接法では, タンパク質基準での PFC相への取込み は，一定量以上の PFBC 添加では，添加したタンパク質 のほぼ全量が取り込まれた。しかし， $0.1-0.2 \mathrm{~cm}^{3} /\left(\mathrm{dm}^{3}\right.$ - PFC) 以下の $\mathrm{PFBC}$ 添加量では安定な $\mathrm{PFC}$ 液滴を得る ことができなかった．直接法でのタンパク質のPFC液滴 相への担持条件の検討の一例として, Fig. 1 に $\beta$-グルコ シダーゼの PFC 相取込みにおける PFBC 添加量の影響を 示す. PFBC 添加量の増加に伴い, $\mathrm{PFC}$ 相ヘタンパク質 が取り込まれる割合は増加したが，活性基準でみると， $\mathrm{PFBC}$ 添加量が $0.5 \mathrm{~cm}^{3} /\left(\mathrm{dm}^{3}-\mathrm{PFC}\right)$ より多くなると取 込み率が減少した。てれはタンパク質が過剩な $\mathrm{PFBC}$ 修 飾により活性を失うためと考えられる。他のタンパク質 での結果ああわせて考えて、 $0.5-1 \mathrm{~cm}^{3} /\left(\mathrm{dm}^{3}-\mathrm{PFC}\right) の$ PFBC 添加量が取込み量之活性の保持のために適当な量 であると考えられる. 本法は, Eveleighらの方法 ${ }^{2,5)}$ と比 ベ, タンパク質の PFC 相への担持に煩雑な操作を必要と せず簡便なため, タンパク質固定化PFCを工業的に利用 するための大量調製に向いていると考えられる.

デキストラン媒介法では, 直接 PFC液滴相にタンパク 質が導入されるとタンパク質の活性部位がPFCによって 妨害を受ける可能性があるのではないかと考えて，媒介 


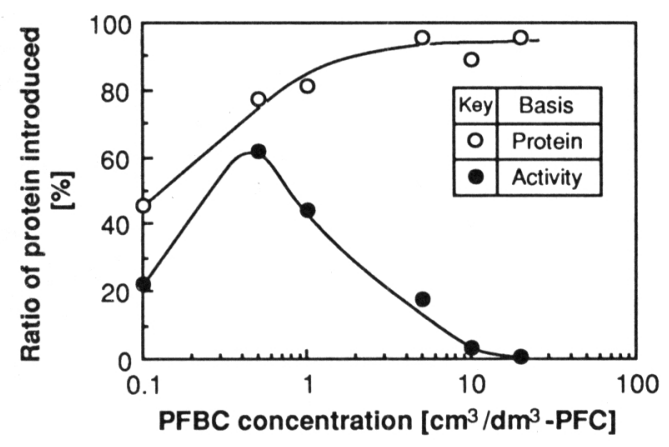

Fig. 1 Effect of PFBC concentration on protein introduction to $\mathrm{PFC}$ phase

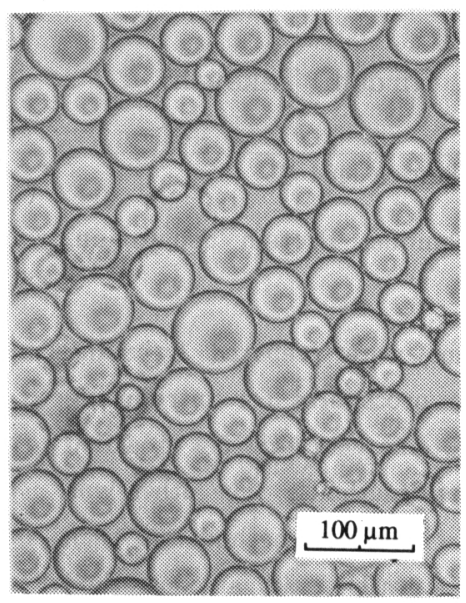

Fig. 2 Photograph of PFC droplets introduced protein

物を介してタンパク質をPFC液滴相に担持したものであ る. Table 1亿見られるように, ての方法では, タンパ ク質の取込み量は直接法に比べて概して低い值となった。 しかし抗体之特異的な親和性をむつプロティン Aの PFC 相への担持の場合，担持されたタンパク質量に対する抗 体吸着量は, 直接法に比べて高い値を示した。このよう に，タンパク質によってはスペーサー効果が期待できる 媒介物を介した固定化が本法でも重要であると考えられ る.

Fig. 2 亿，直接法により調製したPFC液滴の写真を示 す.タンパク質の種類, PFBC や担持したタンパク質量 によって若干液滴径の分布は異なるが, 直径約 20-80 $\mu \mathrm{m}$ の液滴が得られた。液滴を微小化することにより， 全表面積が大きくなるため液滴に担持されるタンパク質 の量は増大できるが, 小さい液滴ほど沈降分離に時間を 要するため適当な液滴径が存在すると考えられる。また 得られた液滴は, 緩衝液中で 3 力月以上安定であった。

リガンド修飾 PFC 液滴相を用タンパク質の吸着回収の
Table 2 Recovery of horseradish peroxidase from $\mathrm{PFC}$ phase introduced concanavalin A

\begin{tabular}{|c|c|c|c|}
\hline & & \multicolumn{2}{|c|}{ Added PFBC $\left[\mathrm{cm}^{3} / \mathrm{dm}^{3}-\mathrm{PFC}\right]$} \\
\hline & & 0.5 & 1.0 \\
\hline Adsorption & {$[\mathrm{mg}]$} & 0.286 & 0.286 \\
\hline Recovery & {$[\mathrm{mg}]$} & 0.150 & 0.133 \\
\hline Yield & {$[\%]$} & 52.4 & 46.4 \\
\hline
\end{tabular}

Concanavalin A-introduced PFC phase: $1 \mathrm{~cm}^{3}$. Eluant: $0.2 \mathrm{M} \alpha$-D - methylmannoside.

Table 3 Amount of horseradish peroxidase adsorbed to $\mathrm{PFC}$ phase introduced concanavalin A during reuse

\begin{tabular}{|c|c|c|c|c|}
\hline \multirow{3}{*}{ Cycle } & \multicolumn{4}{|c|}{ Adsorbed POD $\left[\mathrm{g} / \mathrm{dm}^{3}-\mathrm{PFC}\right]$} \\
\hline & \multicolumn{4}{|c|}{ Added PFBC $\left[\mathrm{cm}^{3} / \mathrm{dm}^{3}-\mathrm{PFC}\right]$} \\
\hline & 0.5 & 1.0 & 5.0 & 10.0 \\
\hline 1 & 0.274 & 0.357 & 0.015 & 0.017 \\
\hline 2 & 0.286 & 0.286 & - & - \\
\hline $3 \ldots$ & 0.235 & 0.263 & - & - \\
\hline \multicolumn{5}{|c|}{ Concanavalin A-introduced PFC phase $: 1 \mathrm{~cm}^{3}$} \\
\hline
\end{tabular}

可能性を検討するため, 糖タンパク質に群特異的に親和 性を持つコンカナバリン A ( Con A) を取り込んだPFC液 滴を直接法により調製し, 西洋わさび由来のパーオキシ ダーゼ(POD)の吸着分離を行った。乙の場合もConA取 込みにおける $\mathrm{PFBC}$ 添加量の最適量が存在する。 すなわ ち, $0.5-1 \mathrm{~cm}^{3} /\left(\mathrm{dm}^{3}-\mathrm{PFC}\right)$ が適量であり，それ以上で はConA は全量PFC相に取り込ま扎たが, POD 吸着量 は急激に低下した。

$1 \mathrm{~g} / \mathrm{dm}^{3}$ の濃度の POD 溶液 $1 \mathrm{~cm}^{3}$ 之約 $1 \mathrm{~g} /\left(\mathrm{dm}^{3}-\mathrm{PFC}\right)$ の濃度で Con A を担持した $\mathrm{PFC}$ 液滴 $1 \mathrm{~cm}^{3}$ とを接触させ てPODの吸着分離を試みたところ，加えたPODの約 60 \%が PFC 液滴相に分配された。 PFC 液滴相を洗浄後， $0.2 \mathrm{M} \alpha$-D -メチルマンノシドを溶出剂として用いて水相 に回収した (Table 2)。いずれの条件でも PFC 液滴に吸 着したPOD量の約 50\%を回収するてとができた、Table 3 は, Con A 修飾PFC液滴の繰返し使用に打ける POD 吸着量の変化を示している. 繰返し使用によって若干 POD 吸着量が低下していくあのの，こてで調製したPFC 液滴はPODの吸着分離に対し絽返し使用することが可 能であった。

以上のように, 本研究で開発した方法によってタンパ ク質の活性を維持した状態で酒滴としてPFCにタンパク 質を簡単・迅速に取り込ませることが可能であった。モ デル系としてConA を取り込ませたPFC液滴を用いて， 西洋わさび由来の POD の吸着回収に繰返し使用できる ことを示した。 
[謝辞] 本研究は文部省科学研究費奨励研究 $\mathrm{A}$ (04750771) の援助を受けました。また，FC-43は住友 $3 \mathrm{M}$ (株) より提供していただきました。ここに深く感謝いたします。

\section{Literature cited}

1) Albertsson, P.- $\AA$.: Partition of cell particles and macromolecules, 3rd ed., Wiley, New York (1986)

2) Boedeker, A.R. and A.M. Lenhoff: Biotechnol. Prog., 5, 132-135 (1989)

3) Goklen, K.E. and T.A. Hatton: Sep. Sci. Technol.
22, 831-841 (1987)

4) Hamamoto, K., M. Tokashiki, Y. Ichikawa and H. Murakami: Agric. Biol. Chem., 51, 3415-3416 (1987)

5) Kobos, R.K., J.W. Eveleigh and R.A. Arentzen : Trends Biotechnol., 7, 101-105 (1989)

6) Lowry, O.H., N.J. Rosebrough, A.L. Farr and R. J. Randall: J. Biol. Chem., 193, 265-275 (1951)

7) Mattiasson, B. and P. Adlercreutz: Trends Biotechnol., 5, 250-254 (1987)

\title{
Preparation of Perfluorocarbon Droplets Containing Proteins and Their Application to Protein Separation
}

\author{
Masamichi Kamihira, Noriaki Ogino and Hiroshi Takeuchi
}

Dept. of Chem. Eng., Nagoya Univ., Nagoya 464-01

Key Words : Biochemical Engineering, Separation Technique, Protein Separation, Perfluorocarbon, Affinity Ligand

Perfluorocarbon (PFC) droplets containing proteins were prepared by using perfluorobenzoyl chloride (PFBC) as a modifier. Two procedures for introducing proteins to PFC phase were examined. One was that proteins were directly modified with PFBC to partition the protein to PFC phase (direct method). The other was that dextran was first introduced to PFC droplets by the direct method and then proteins were immobilized through the dextran by using a $\mathrm{NaIO}_{4}$ oxidization method (dextran-mediated method). In the direct method, there was an optimal concentration of PFBC to obtain maximal activity of the protein introduced. PFC droplets introduced concanavalin A were used for adsorption and separation of horseradish peroxidase (POD). The PFC droplets could adsorb $60 \%$ of POD added and $50 \%$ of POD adsorbed was recovered from the PFC phase. Moreover, the PFC droplets could be repeatedly used for adsorption and elution of POD. 